\title{
Migrasi Orang Biak di Kota Jayapura
}

\author{
Alfasis Romarak Ap ${ }^{\mathrm{a}, 1^{*}}$, Renny Thereesje Tumober $\mathrm{b}, 2$, Febriani Safitri ${ }^{\mathrm{c}, 3}$ \\ abc Universitas Cenderawasih, Jalan Kampwolker Waena, Jayapura-Papua, 99351, Indonesia \\ ${ }_{1}^{1}$ araprom47@gmail.com;2 rennytumober2204@gmail.com; ${ }^{3}$ geofebrhy@gmail.com \\ Corresponding Author
}

\begin{tabular}{l}
\hline INFO ARTIKEL \\
\hline Sejarah Artikel: \\
Diterima: 27 Februari 2021 \\
Direvisi: 27 Maret 2021 \\
Disetujui: 4 April 2021 \\
Tersedia Daring: 10 April 2021 \\
\hline Kata Kunci: \\
Kota Jayapura \\
Migrasi \\
Orang Biak
\end{tabular}

\begin{abstract}
ABSTRAK
Penelitian ini merupakan penelitian dalam aspek geografi sosial. Tujuan penelitian ini adalah mengetahui pola migrasi dan faktor penyebab orang Biak bermigrasi ke Pantai Base-G Kota Jayapura. Metode yang digunakan dalam penelitian ini adalah deskriptif kualitatif. Alasan penggunaan metode ini adalah karena teknik wawancara yang digunakan lebih banyak menggunakan wawancara mendalam terhadap informan-informan kunci termasuk penduduk setempat yang mengetahui riwayat pola migrasi dan faktor penarik orang Biak datang ke Pantai Base-G Kota Jayapura. Hasil penelitian menunjukkan bahwa migran orang Biak datang ke Jayapura karena alasan keamanan di daerah asalnya dan sebelumnya sudah ada orang Biak, yang merupakan keluarga dekat, telah menempati daerah tersebut. Alat transportasi yang pertama kali digunakan ketika datang ke Jayapura adalah kapal perintis. Alasannya karena pada saat itu belum ada kapal berukuran besar yang melayani transportasi dari Biak ke Jayapura. Migran orang Biak di BaseG baru mulai menempati Base-G tahun 1984. Sebelumnya, mereka bertempat tinggal di beberapa kawasan pemukiman penduduk di Kota Jayapura, Abepura, dan Sentani karena alasan belum mempunyai rumah. Penduduknya bertambah jumlahnya menjadi 147 jiwa. Migran orang Biak di Base-G saat ini berprofesi tetap sebagai nelayan, di samping bekerja sebagai buruh bangunan.
\end{abstract}

\begin{tabular}{ll}
\hline ABSTRACT \\
\hline Keywords: & This article is a research in the aspect of social geography. The purpose of \\
Jayapura City & this study was to determine the migration patterns and factors that attract \\
Migration & the Biak people to migrate to Base-G Beach of Jayapura City. The method \\
Biak People & the interview technique used that mostly use in-depth interviews with key \\
informants including local residents who have the knowledge of the history \\
of migration patterns and the attracting factors of the Biak people to the \\
Base-G Beach, Jayapura City. The results showed that Biak migrants came \\
to Jayapura for security reasons in their home areas and previously there \\
were Biak people, who were close relatives, who had occupied the area. \\
The first means of transportation used when they came to Jayapura were \\
pioneer ships. The reason was because at that time there were no large \\
ships serving transportation from Biak to Jayapura. Biak migrants at Base- \\
Gonly started to occupy Base-G in 1984 . Previously, they lived in several \\
residential areas in Jayapura, Abepura, and Sentani cities because they did \\
not have a house. The population has increased to 147 inhabitants. Biak \\
migrants at Base-G currently work as fishermen, in addition to working as \\
construction workers.
\end{tabular}




\section{Pendahuluan}

Migrasi penduduk di berbagai daerah di dunia telah berlangsung sejak manusia mulai menghuni Bumi. Migrasi penduduk dapat terjadi antarpulau, negara, atau benua karena berbagai alasan. Pada negara-negara di benua Eropa dan Afrika, migrasi penduduk terjadi karena persoalan keamanan dan kekurangan pangan. Di negara-negara benua Asia, migrasi penduduk terjadi karena alasan yang sama. Migrasi penduduk di kota-kota besar di Indonesia pada umumnya terjadi karena ingin mengadu nasib di daerah tujuan dan alasan gangguan keamanan.

Pulau Jawa, sebagai salah satu pulau terpadat penduduknya di Indonesia dan pusat pemerintahan, menjadi salah satu penyuplai migrasi terbesar ke berbagai kawasan Indonesia, seperti pulau Sumatera, Kalimantan, dan Papua. Untuk mendatangi daerah baru berbagai cara dapat dilakukan. Misalnya, menghubungi kerabat terdekat untuk menanyakan situasi daerah terbaru yang ingin didatangi atau langsung mengikuti sanak saudara yang berlibur ke daerah asal dengan memanfaatkan sarana transportasi yang memungkinkan. Entah dengan menggunakan pesawat terbang, atau yang lebih murah menumpang kapal-kapal penumpang PELNI laut.

Tanah Papua memiliki kurang-lebih 275 suku etnis dan bahasa. Secara tradisional penyebaran suku-suku tersebut cenderung terkonsentrasi di wilayah-wilayah adat budaya masing-masing (Huwae et. al., 2018). Meskipun demikian keberagaman ini menjadi potensi sosial dalam kehidupan suku-suku tersebut. Mereka saling mengenal dan menghormati satu sama lain sebagai manusia Papua. Hal itu dimulai saat pembangunan di berbagai sektor dilakukan, terutama sejak tahun 1980-an hingga hadirnya otonomi khusus bagi Papua. Sejak itu, berbagai kota atau kabupaten di Papua lebih terbuka untuk dimasuki dan menerima keberagaman. Selain migran dari luar, kotakota tertentu di Papua juga didatangi berbagai migran lokal Papua.

Kota Jayapura sebagai ibu kota Provinsi Papua, sejak masa integrasi hingga saat ini, menjadi daerah yang paling banyak didatangi migran dari berbagai daerah di Indonesia. Berbagai macam alasan menjadi penyebab mengapa tanah Papua, khususnya Kota Jayapura menjadi sasaran kaum migran. Hal ini terjadi mulai dari alasan pendidikan, ekonomi (pekerjaan), hingga kesehatan.

Kota-kota kabupaten, hasil pemekaran di daerah, baik di daerah-daerah pesisir maupun pegunungan juga tak kalah menarik minat migran. Karena alasan pekerjaan, berbondong-bondong orang ke kota-kota untuk sementara waktu atau menetap. Jayapura sebagai Ibu Kota Provinsi Papua menawarkan berbagai kemudahan menjadi tujuan utama. Sebut saja, pemukim dari Pulau Biak, khususnya Distrik Biak Barat di Pantai Base-G, Distrik Jayapura Utara. Mereka setidaknya, sudah bermukim di sini, kurang-lebih 35 tahun. Adapun alasannya ke Jayapura karena persoalan keamanan dan ingin mencari pekerjaan (wawancara dengan Ibu Rahel Krey).

Kawasan Pantai Base-G secara administratif berada dalam wilayah Kelurahan Tanjung Ria, Distrik Jayapura Utara, Kota Jayapura. Pantai Base-G merupakan basis pangkalan perang masa kolonial. Sepanjang pesisir pantai Utara Papua, di masa Perang Dunia II dijadikan sebagai dirikan basis (kubu) pertahanan oleh pasukan sekutu, pimpinan Amerika Serikat. Dari sinilah nama-nama basis diwariskan, misalnya, Base-A hingga Base-G. Saat ini, Pantai Base-G adalah salah satu obyek wisata di Kota Jayapura yang ramai dikunjungi di saat-saat libur atau senggang. Walaupun awalnya pengelolaannya belum dilakukan dengan baik oleh pemilik hak 
ulayat setempat karena belum ramai dikunjungi seperti sekarang.

Migrasi orang Biak ke kawasan ini diperkirakan terjadi sejak 1968. Mereka umumnya berasal dari Kampung Adadikam, Distrik Biak Barat. Hal ini dapat diketahui dari marga-marga asal Biak di tempat ini yang semuanya berasal dari kampung ini. Banyak faktor yang mempengaruhi penduduk untuk melakukan migrasi, misalnya, faktor aksesibilitas, ekonomi, pendidikan, budaya merantau, atau terjadinya konflik di daerah asal (Sudubia et. al., 2012).

Beberapa penelitian yang relevan dengan penelitian ini sebagai berikut. Pertama, Frank et. al., (2015) meneliti tentang orang Biak di Kepulauan Komamba Sarmi-Papua. Dalam penelitiannya diceritakan tentang keberadaan orang-orang Biak yang saat ini tinggal dan hidup di luar pulau Biak. Dalam kehidupan masyarakat, hidup cerita sejarah yang tidak terlupakan mengenai kisah-kisah heroik dalam perjalanan migrasi, seperti keberanian dalam mengarungi lautan, terampil dalam berdagang, tangguh dalam menyerang musuh, handal dan diplomatis dalam membangun hubungan-hubungan sosial, dinamis dalam perubahan sosial dan kebudayaan, serta sukses menciptakan penemuan-penemuan untuk kebutuhan. Berbagai perkembangan tersebut berhasil karena kemampuan adaptasi terhadap situasi dan kondisi alam sekitar untuk pemenuhan kebutuhan-kebutuhan hidup (survive). Dalam keterbatasan, orang Biak tidak melupakan cerita-cerita lisan, mite ataupun legenda, dan cerita tersebut mempengaruhi alam pikiran orang-orang Biak untuk mengambil keputusan melakukan perjalanan-perjalanan keluar, baik dalam misi Hongi ataupun berperang. Semua yang telah dilakukan adalah dengan melihat kebutuhan-kebutuhan di tempat lain dan memanfaatkan situasi untuk kepentingan mereka. Bersamaan dengan itu pengalaman terhadap kehidupan masyarakat dengan sistem stratifikasi turut menjadi dorongan untuk melakukan hal yang sama (Frank et. al., 2015).

Kedua, penelitian yang dilakukan oleh Saberia, et. al., (2016), memperlihatkan orang Tobelo yang lebih memilih Lemalas dibandingkan Waigama untuk tempat menetap sepanjang hayat. Hal ini dikarenakan dua alasan pokok. Pertama, masyarakat Matbat yang ada di Lemalas belum memiliki agama resmi sehingga sangat terbuka menerima kedatangan orang Tobelo, bahkan bersedia menyediakan lahan untuk mengumpulkan makanan bagi orang Tobelo. Kedua, perbedaan keyakinan yang diperlukan oleh masyarakat Waigama dengan orang Tobelo. Masyarakat Waigama pada saat itu memeluk Islam dan orangorang Tobelo pemeluk agama kristen protestan. Menurut Bapak Yance Maspaitella, salah seorang informan penelitian, kedatangan masyarakat Tobelo ke Misool Timur bukan karena kemauan sendiri, melainkan pada waktu itu untuk mencari hasil laut berupa bia lola, teripang, dan bulu burung Cenderawasih untuk dijual ke penadah. Selain itu, ada alasan lain yang mendorong masyarakat Tobelo meninggalkan kampung halaman mereka yaitu faktor ekonomi dan sosial, serta adanya wabah penyakit yang tidak kunjung sembuh, yang mengakibatkan mereka keluar dan kampung halaman mereka untuk menghindari penyakit tersebut. Misool dipilih karena tempat tersebut tidak terlalu jauh dari Tobelo dan orang Tobelo pernah berkunjung ke sana sebelumnya. Untuk itu, kedatangan orang Tobelo di Misool dapat diterima oleh masyarakat setempat.

Lambat laun hubungan masyarakat Tobelo dengan masyarakat Matbat semakin dekat. Hal ini yang membuat rencana untuk membuka kampung di wilayah ini dapat terlaksana. Hal ini karena telah adanya hubungan persaudaraan dengan janji adat kedua bela pihak di Kampung Lemalas Misool. Hal tersebut terlihat dengan adanya Orang Matbat yang memberikan tanah hak ulayat mereka kepada orang Tobelo untuk dibangun pemukiman bersama-sama dengan masyarakat Matbat di Kampung Lemalas. 
Bukan hanya tanah untuk membangun pemukiman saja, masyarakat Tobelo juga memberikan satu dusun untuk tempat mereka mencari makan (Saberia, et. al., 2016).

Orang Biak dikenal dengan keterampilannya dalam pelayaran. Dibekali dengan pengetahuan tentang alam, astronomi, dan teknologi pelayaran menjadikan mereka telah melakukan pelayaran ke bagian Barat, Timur, dan bahkan luar Pulau Papua sebelum abad 15. Beberapa daerah bahkan dijadikan sebagai tempat tujuan menetap atau migrasi (Usmany, 2014). Jadi, tidak heran jika beberapa daerah di wilayah pesisir Papua sering ditemukan pemukiman migran Biak, seperti di Pulau Batanta, Kabupaten Raja Ampat (Maryone, 2010), di Sausapor, Papua Barat (Oktafiani \& Jagaswara, 2019), dan di Pantai Base-G, Kota Jayapura yang menjadi daerah kajian peneliti.

Status Kota Jayapura sebagai Ibu Kota Provinsi Papua banyak memberikan kemudahan dalam perolehan lapangan kerja menjadi salah satu alasan migran Biak Barat bermigrasi ke Jayapura pada saat itu. Perpindahan pemukim Base-G ini berlangsung secara bertahap ke Pantai BaseG, Kota Jayapura. Penelitian ini bertujuan mendeskripsikan bagaimana pola migran orang Biak Barat di Pantai Base-G Kota Jayapura dan apa faktor- faktor pendorong dan penarik migran Biak Barat ini.

\section{Metode}

Pendekatan yang digunakan dalam penelitian ini adalah kualitatif. Penelitian kualitatif karena menelisik tradisi dan praktik hidup masyarakat (Ahimsa-Putra, 2009). Penelitian yang dilakukan pada migran Biak Barat, didasarkan pada bagaimana migran Biak Barat datang ke Jayapura dan apa faktor penarik atau faktor pendorongnya. Oleh karena itu teknik pengumpulan data yaitu dengan mewawancarai seluruh migran yang mempunyai rumah di lokasi penelitian, sebanyak 20 kepala keluarga, melalui wawancara, observasi, dan dokumentasi.
Peneliti menggunakan observasi untuk mengetahui pola migrasi serta faktor pendorong dan penarik masyarakat suku Biak Barat di Pantai Base-G. Observasi yang dilakukan penulis berdasarkan pengalaman empirik pribadi penulis sejak penulis pertama kali datang di Jayapura pada 1986 di mana pada saat itu belum ada migran asal Biak yang menempati kawasan tersebut seperti sekarang. Di samping itu penulis juga mewawancarai salah satu migran yang mengetahui secara pasti riwayat migrasi orang Biak di daerah tersebut hingga saat ini. Selain itu observasi juga dilakukan untuk mengetahui aktivitas sehari-hari penduduk setempat. Wawancara dilakukan dengan cara melakukan komunikasi dua arah antara pencari data dan salah satu responden di lokasi penelitian dengan menggunakan wawancara terstruktur. Kemudian juga dilakukan dokumentasi berupa gambar aktivitas masyarakat suku Biak di Pantai Base-G.

Data-data tersebut diperoleh langsung dari informan yang terpilih. Sumber data penelitian adalah data primer yang diperoleh secara langsung di lapangan dari informan kunci, antara lain pimpinan masyarakat kampung asal Biak Barat di Pantai Base-G dan Ketua Ikatan Masyarakat Biak. Lalu data sekunder yang diperoleh baik dari instansi-instansi pemerintah, perpustakaan, maupun pihak-pihak lainnya. Untuk mencapai suatu tujuan penulisan yang benar (valid), penjaringan data disesuaikan dengan permasalahan yang sedang teliti. Data diperoleh secara langsung dari Kantor Kelurahan Tanjung Ria, Distrik Jayapura Utara serta kajian pustaka dari dinas terkait. Data yang telah diperoleh kemudian dianalisis secara deskriptif.

\section{Hasil dan Pembahasan}

\subsection{Asal Usul Base-G}

Base-G adalah basis pangkalan perang masa kolonial. Sepanjang pesisir pantai Utara Papua, sejak Belanda menduduki Papua, beberapa lokasi di pesisir Utara Papua didirikan basis perang yang penyebutan namanya dimulai dari sebutan 
Base-A hingga terakhir Base-G. Lokasi pemukiman penduduk orang Biak saat ini merupakan bekas basis pangkalan perang tentara Belanda pada tahun 1940-an. Saat ini Pantai Base-G menjadi salah satu obyek wisata bahari di Kota Jayapura. Sebelum lokasi ini dijadikan daerah wisata bahari di Kota Jayapura, masyarakat Kota Jayapura saat itu pada waktu senggang memilih Pantai Base-G sebagai tempat berwisata karena memiliki pasir dan bebatuan. Sejak itu lokasi di pantai ini belum dikelola secara tetap oleh pemilik hak ulayat setempat karena belum ramai dikunjungi seperti sekarang. Pemukiman di kawasan pantai Base-G juga semakin berkembang.

Pemilik Hak Ulayat lokasi tempat tinggal orang Biak di Pantai Base-G saat ini adalah penduduk asli dari Kampung Kayu Batu Kota Jayapura yang berasal dari Marga "Pui" atas nama Bapak Yudas Pui. Atas persetujuan Bapak Yudas Pui lokasi pemukiman orang Biak saat ini di Pantai Base-G diberikan kepada Bapak Frits Krey yang pada saat ini bekerja sebagai penjaga bar (tempat hiburan) milik Pemerintah Belanda pada saat itu (sebelum peralihan Indonesia dari pemerintah Belanda ke Indonesia) pada 1968. Lokasi tempat tinggal orang Biak di Pantai Base-G menurut bahasa lokal pemilik hak ulayat setempat disebut "mora" yang oleh penduduk setempat diartikan sebagai "ini tanah".

\subsection{Keberadaan Migran Biak di} Kawasan Pantai Base-G

Pemukiman orang Biak di Pantai Base$\mathrm{G}$ termasuk dalam Rukun Tetangga 08 dan Rukun Warga 01, Kelurahan Tanjung Ria, Distrik Jayapura Utara. Pemukiman penduduknya dibangun di atas daerah Bating Gisik kawasan Base-G dan dibatasi lintasan gisik yang menghadap ke wilayah pasang surut (zona pecah gelombang). Kawasan ini terletak pada $2^{0} 30$ ' 39.34 " LS-2 ${ }^{0} 30^{\prime} 43.95^{\prime \prime}$ LS dan $140^{\circ} 44^{\prime} 4.45^{\prime \prime}$ BT - $140^{\circ} 44^{\prime} 11.45^{\prime \prime}$ BT. Secara administratif pemukiman penduduk orang Biak di sisi Utara Pantai Base-G dengan batas-batas wilayah sebagai berikut. Di sebelah Utara berbatasan dengan sebagian lokasi wisata bahari pantai Base-G, sebelah Selatan berbatasan dengan sebagian lokasi wisata bahari pantai Base-G, sebelah Timur berbatasan dengan batas pasang surut air laut, dan sebelah Barat berbatasan dengan daerah back swam dan lintasan buritan.

Luas Pemukiman Orang Biak di Pantai Base-G saat sekitar $14.208 \mathrm{~m}^{2}$, memiliki daerah yang datar dan mengikuti garis pantai, dan dibatasi oleh daerah back swam (daerah belakang) yang sedikit berawa dan ditumbuhi vegetasi rawa. Lokasi permukiman tersebut awalnya diperuntukan sebagai lokasi wisata bahari, bila migran asal Biak di daerah tersebut dimukimkan di lokasi lain yang dianggap strategis. Meskipun sampai saat ini belum jelas status relokasi lokasi pemukiman tersebut karena berbenturan dengan lokasi strategis lainnya yang berkaitan dengan perrsoalan hak ulayat dan kelayakan lokasi yang dimaksud dari aspek sanitasi lingkungan.

Penduduk migran asal Biak di Pantai Base-G berjumlah 147 jiwa, terdiri dari 43 kepala keluarga dan tersebar dalam 18 rumah milik penduduk setempat dengan angka beban tanggungan sebanyak 107 orang dari 147 jiwa yang mana jumlah anak yang belum sekolah sebanyak 29 orang anak $(27,10 \%)$. Dari status perkawinan penduduk setempat, hanya 12 kepala keluarga yang sudah menikah resmi di gereja, sedangkan 4 kepala keluarga belum menikah gereja meskipun sudah kawin dan mempunyai anak, dan 4 kepala keluarga berstatus janda. Selain itu dari letak sosial-ekonomi sangat strategis untuk pengembangan daerah wisata karena berada di pengembangan wisata bahari Pantai Base-G Kota Jayapura sehingga akses transportasi darat yang lancar dan berdampak bagi kehidupan.

Berdasarkan perkembangan pemerintahannya di tingkat distrik, Base-G pernah diusulkan menjadi satu kampung tersendiri sama seperti pembentukan kampung-kampungnya lainnya di wilayah pemerintahan kota Jayapura, namun berdasarkan pertimbangan status dan perkembangan daerah sekitarnya akhirnya ditetapkan sebagai salah satu Rukun 
Tetangga 08 (RT) dalam sepuluh RT yang berada di bawah wilayah kekuasaan Rukun Warga 01 (RW). Terlepas dari sisi pemerintahan, migran asal Biak di kawasan tersebut membentuk sistem pemerintahan adat yang terwariskan dari kampung halamannya di Biak, sehingga beberapa orang tua di tempat tersebut diangkat dan ditetapkan sebagai tokoh adat yang terdiri dari tokoh adat, wakil ketua, penasihat atau pendamping, ketua peradilan adat, dan penasihat.

Topografi perkampungan migran orang Biak di Pantai Base-G relatif datar dan terletak di daerah bating gisik dan ke arah Baratnya dibatasi oleh daerah back swam dan beberapa lintasan lahan buritan. Jenis tanah sekitarnya adalah jenis tanah alluvial pantai sebagai akibat dari penimbunan oleh aktivitas gelombang dan angin pada masa lampau. Kondisi topografi yang demikian berpotensial untuk migran setempat membangun rumah di atas daerah bating gisik daerah sekitar karena memudahkan pembangunan rumah bagi penduduk setempat.

Jenis tanah di daerah pemukiman orang Biak di Pantai Base-G termasuk dalam kelompok jenis tanah alluvial pantai, sebagai akibat dari penimbunan oleh aktivitas gelombang atau angin. Jenis tanah di daerah sekitar cocok untuk tanaman kelapa, ketapang, bitanggur, pandanus, dan barintonia. Jenis tanaman tersebut merupakan tanaman spesialis pantai karena mempunyai kemampuan menyerap kadar garam. Seperti halnya daerah back swam di sisi Barat pemukiman orang Biak di Base-G terdiri dari sebaran vegetasi berupa sagu, pandanus, nipah, riparian yang merupakan jenis rerumputan yang tumbuh di rawa.

\subsection{Karakteristik Migran Biak di Kawasan Pantai Base-G}

Untuk mengetahui karakteristik responden di lokasi penelitian pada pemukiman migran orang Biak di Pantai Base-G Kelurahan Tanjung Ria Distrik Jayapura Utara Kota Jayapura, dilakukan analisis beberapa aspek kependudukan yang berkaitan dengan umur, tingkat pendidikan, status perkawinan, pekerjaan tetap dan pekerjaan sambilan, jumlah tanggungan dalam keluarga, pendidikan anak-anakk responden, status perkawinan anak-anak responden

Migran orang Biak di Pantai Base-G lebih banyak didominasi migran yang berusia antara 40-44 tahun, 55-59 tahun dan 50-54 tahun. Selain usia antara 30-34 tahun.

Secara umum dapat dikatakan bahwa usia responden yang saat ini mendiami pemukiman penduduk di Pantai Base-G Kota Jayapura, pada umumnya merupakan penduduk usia produktif. Salah satu studi di tentang Migrasi di Bali misalnya pelaku migrasi yang masuk Kota Bali didominasi oleh laki-laki pada kelompok umur 20-39 tahun. Berdasarkan status perkawinan, pelaku migrasi masuk ke Kota Denpasar didominasi oleh responden dengan status kawin yaitu sebesar 52 persen (Trendyarti \& Yasa, 2014). Situasi yang demikian menggambarkan status perkawinan migran orang Biak di Pantai Base-G.

Teori Ravenstein menyebutkan bahwa penduduk yang masih muda dan belum menikah lebih banyak melakukan migrasi dibandingkan dengan mereka yang berstatus sudah menikah. Hal ini juga disebabkan karena penduduk yang belum menikah melakukan migrasi untuk mencari pengalaman baru di tempat tujuan dan berharap dapat menemukan pekerjaan yang lebih layak dengan pendapatan yang lebih tinggi sehingga memilih untuk melakukan migrasi (Sasmi \& Bachtiar, 2014).

Migran orang Biak di Pantai Base-G sebagian besar berpendidikan SLTA, selain berpendidikan SMP dan SD. Hanya sebagian kecil yang berpendidikan S1. Sebagian besar migran orang Biak di Base$\mathrm{G}$ berada pada tingkat pendidikan menengah pertama dan menengah atas. Hal ini disebabkan oleh riwayat migrasi responden yang sebelum mendiami daerah tersebut, sebelumnya berasal dari kampung halamannya di Biak yang pada saat itu (sekitar tahun 1970 an dan 1980 an) belum tersedia Sekolah Menengah Atas dan 
Sekolah Menengah Pertama, termasuk pembangunan jalan yang menghubungkan Biak Kota dan distrik Biak Barat seperti yang saat ini. Di samping itu juga mencekamnya situasi politik pada era 1960an hingga 1980-an yang memperkecil peluang untuk bersaing dalam dunia pendidikan menengah hingga pendidikan tinggi. Rendahnya tingkat perekonomian keluarga juga merupakan faktor lain yang juga ikut mempengaruhi. Hasilnya, hanya beberapa orang saja yang dapat meraih pendidikan di tingkat menengah pertama dan menengah atas yang seluruhnya diselesaikan di Kota Biak.

Pada bagian yang lain Teori Ravenstein (Sasmi \& Bachtiar, 2014), menyebutkan bahwa penduduk yang mempunyai tingkat pendidikan tinggi biasanya lebih tinggi mobilitasnya dibandingkan yang berpendidikan rendah. Hal ini secara umum menunjukkan bahwa tingkat partisipasi migrasi meningkat dengan meningkatnya tingkat pendidikan. Pendidikan yang tinggi akan mempengaruhi pola pikir individu untuk memperoleh pendapatan yang lebih baik. Meningkatnya Pendidikan tersebut secara nyata juga akan meningkatkan pendapatan migran, sehingga dapat menurunkan biaya migrasi.

Berdasarkan hasil analisis data primer yang dilakukan di lokasi penelitian, diketahui bahwa untuk status perkawinan migran Biak di Base-G tidak semua migran orang Biak yang saat ini mendiami Pantai Base-G mempunyai riwayat waktu pernikahan yang sama. Hal ini disebabkan oleh usia responden dan lama menempatinya kawasan pemukiman di Pantai Base-G saat ini. Sebagian besar menikah di Jayapura dengan istrinya dan sisanya sebelum ke Jayapura sudah menikah resmi dengan istrinya. Hal ini disebabkan oleh migran orang Biak yang menikah dengan riwayat pernikahan yang relatif didominasi dari penduduk yang menikah di Jayapura, menggambarkan bahwa sebagian besar migran orang Biak yang ada saat ini sebagai buruh bangunan. (Hasil wawacara dengan penduduk setempat).
Untuk istri migran orang Biak yang saat ini tinggal di kawasan pantai Base-G Kota Jayapura berasal dari Pulau Biak, selain dari Pulau Yapen. Banyaknya istri migran asal Biak yang lebih banyak berasal dari Biak menunjukkan bahwa rata-rata migran asal Biak yang diwawancarai berasal dari satu distrik dan satu kampung (Distrik Biak Barat dan Kampung Adadikam).

Selama di Jayapura migran orang Biak di Pantai Base-G mempunyai pekerjaan tetap sebagai buruh bangunan, selain sebagai wiraswasta. Pekerjaan sebagai buruh bangunan didasari oleh migran di mana sejak menempati kawasan pantai Base-G sebelumnya berasal dari kampung halamannya dan bekerja sebagai petani. Ketika datang di Kota Jayapura yang sama sekali tidak menjanjikan pekerjaan sebagai petani, maka bermodalkan pengalaman sebelumnya yang dipelajari dari sesama migran asal Biak lainnya yang sudah lebih dahulu datang di Jayapura dan bekerja sebagai buruh bangunan, sebagian migran mengaku memiliki pekerjaan tetap sebagai buruh bangunan.

Sebagai Ibu Kota Provinsi Papua, berbagai pembangunan fisik, seperti rumah, jalan, dan jembatan, baik yang dilakukan oleh pemerintah maupun penduduk lainnya yang bermodal sebagai pengusaha terus mengembangkan proyek-proyek pemukiman, sanitasi lingkungan, dan insfrastruktur lainnya yang tentu membutuhkan banyak pekerja atau buruh. Migran asal Biak yang saat ini menempati kawasan Pantai Base-G Kota Jayapura, ikut mengambil bagian dalam proyek-proyek perumahan pemerintah yang dikerjakan pihak swasta maupun yang dilakukan oleh sekelompok pengusaha untuk kepentingan bisnis. Selain itu juga atas permintaan individu yang membutuhkan tenaga kerja dalam membangun rumah pribadi.

Migran orang Biak di Pantai Base-G selain mempunyai pekerjaan tetap juga mempunyai pekerjaan sambilan sebagai nelayan, penjual pinang, dan buruh bangunan. Migran yang bekerja sebagai nelayan adalah yang bekerja tetap sebagai 
buruh bangunan. Biasanya ketika jarang mendapatkan proyek-proyek bangunan, migran tersebut melakukan pekerjaan sambilan sebagai nelayan. Jika ada panggilan/informasi tentang adanya proyekproyek fisik, pekerjaan sebagai nelayan ditinggalkan untuk sementara waktu dan fokus melakukan pekerjaan sebagai buruh bangunan. Situasi tersebut biasanya disesuaikan dengan musim ikan dan cuaca di laut sekitar tempat yang biasanya digunakan untuk melaut.

Dari 20 responden yang diwawancarai, 1 responden mengatakan mempunyai tanggungan sebanyak 15-19 orang. Banyaknya tanggungan ini terdiri dari keluarga baru yang terdiri dari tiga kepala keluarga dengan istri dan anak-anak. Ada beban tanggungan yang sangat besar karena dari sisi daya tampung rumah, seharusnya di rumah setiap kepala keluarga tersedia kurang lebih 5 kamar untuk menampung banyaknya jumlah anggota keluarga dalam rumah. Berdasarkan hasil wawancara yang dilakukan pada beberapa kepala keluarga yang diketahui bahwa di dalam satu rumah terdapat satu hingga tiga kepala keluarga yang sudah memiliki anak istri dan menjadi tanggungan bagi kepala keluarga yang ratarata mempunyai pekerjaan tetap sebagai buruh bangunan dan pekerjaan sambilan sebagai nelayan.

Terdapat anggota keluarga yang sudah menikah dan tinggal bersama-sama dengan responden (kepala keluarga) namun belum mempunyai pekerjaan tetap sehingga berpengaruh terhadap kebutuhan konsumsi keluarga anggota keluarga migran.

\subsection{Sejarah Pemukim Pertama Orang Biak di Pantai Base G}

Orang Biak yang pertama kali menempati pemukiman orang Biak di Pantai Base-G saat ini adalah Bapak Frits Krey dan Istrinya Maria Adadikam pada tahun 1968. (Wawancara dengan Ibu Rahel Krey, anak Bapak Frits Krey pada Agustus 2020). Menurutnya Bapak Frits Krey saat itu bekerja di Hotel Numbay Jayapura yang saat ini berlokasi di Dok 5 Atas. Rumah yang ditempati Bapak Frits Krey saat itu merupakan tempat hiburan (bar) bagi tentara sekutu di Pantai Base-G pada Perang Dunia Kedua. Setelah Bapak Frits Krey, orang Biak yang berikutnya datang untuk menempati pemukiman orang Biak di Pantai Base-G saat ini adalah Bapak Sarewo dan Bapak Timotius Adadikam yang kemudian memilih pindah ke daerah Polimak. Setelah kedua Bapak tersebut, orang Biak lain yang menyusul adalah Bapak Stevanus Krey dan Bapak Sepi Bonggoibo, Darius Bonggoibo dan Dorus Awom. Waktu migrasi mereka dari Biak ke Jayapura-Pantai Base-G dimulai sejak tahun 1977 sampai dengan 1986 dan disusul orang Biak lainnya di Pantai Base-G saat ini yang terus datang ke Jayapura dan menempati Pantai Base-G hingga saat ini (2020).

Bapak Frans Awom yang saat ini ditunjuk sebagai Ketua RT 08 di Pemukiman Orang Biak di Pantai Base-G pertama kali datang ke Jayapura pada tanggal 7 Februari 1987. Pada saat itu, Bapak Frans Awom ketika menginjakkan kakinya di Pelabuhan Jayapura, langsung ke rumah Bapak Frits Krey di Pantai Base-G. Setelah beberapa waktu tinggal dengan Bapak Frits Krey, Bapak Frans Awom memilih membangun rumah sendiri.

Adapun alasan pindah ke Jayapura adalah karena para orang tua di kampung halaman ditangkap dan dipenjara, selain rasa tidak aman, selain karena ingin mencari pekerjaan untuk mencukupi kebutuhan ekonomi dan pendidikan anak di Jayapura.

Husnah (2019), mengemukakan bahwa migrasi keluar dipengaruhi oleh beberapa faktor pendorong. Pertama migrasi dipengaruhi oleh Pendidikan. Pendidikan memainkan peranan utama dalam membentuk kemampuan sebuah negara berkembang untuk menyerap teknologi modern dan untuk mengembangkan kapasitas agar tercipta pertumbuhan serta pembangunan yang berkelanjutan.

Brown dan Sanders (Lausiry \& Tumuka, 2019), mengemukakan bahwa migrasi merupakan akibat adanya kepuasan maupun ketidakpuasan individu maupun 
rumah tangga secara keseluruhan termpat yang ada. Jika kepuasan dari tempat yang baru itu menyimpang dari kebutuhan maupun harapan, maka individu akan mempertimbangkan untuk mencari lokasi baru.

Rata-rata orang Biak yang saat ini menempati Pantai Base-G Kota Jayapura dan sudah berkeluarga menikah di kampung halamannya dan juga di Jayapura. Penduduk setempat, seperti Bapak Dorus Awom, Frans Awom, dan Baldus Awom menikah di Kampung Adadikam. Sementara keluargakeluarga baru lainnya menikah di Jayapura. Mayoritas penduduk yang mendiami Pantai Base-G saat ini adalah orang Biak.

Sejak ditempati pertama kali, ada sekitar 15 kepala keluarga dari Biak khususnya Kampung Adadikam Distrik Biak Barat yang saat ini menempatinya. Sebelum menempati daerah Base-G, masyarakat Biak saat itu menempati kawasan Dok 9 Kali. Namun karena kejadian kebakaran lokasi permukiman di Dok 9 Kali, akhirnya penduduk tersebut pindah tempat tinggal ke sisi Utara Pantai Base-G hingga saat ini dan terjadi pertambahan penduduk dan pertambahan jumlah kepala keluarga atau keluargakeluarga baru.

Daerah Base-G sebagai lokasi tempat tinggal saat ini sudah empat kali dilakukan pertemuan antara penduduk setempat dengan pemilik lokasi tempat tinggal mengenai alasan memilik lokasi tersebut karena pertimbangan keamanan. Kawasan ini dianggap aman sehingga dipilih sebagai lokasi tempat tinggal.

Ada upaya untuk lokasi pemukiman di Pantai Base-G pindah ke daerah pemukiman penduduk di Pasir 2 (tepatnya di belakang area Gereja Syalom), namun tidak terbentur dengan biaya pembangunan pemukiman dan infrastruktur yang tentu membebani program pemerintah Kota Jayapura. Upaya lainnya adalah warga setempat ingin dimukimkan di daerah Pasir 2 yang lokasinya terbuka dan belum ada pemukiman apapun, namun masih terbentur dengan hak ulayat orang Ormu dari
Kampung Ormu. Masyarakat Kampung Ormu mempunyai hak ulayat yang menyebar dari Kampung Ormu hingga kawasan Pasir Dua Distrik Jayapura Utara, Kota Jayapura. Akhrinya lokasi pantai BaseG menjadi pilihan tempat tinggal, meskipun saat ini statusnya adalah Hak Pakai.

Atas dasar selembar surat dari Bapak Rumbiak pada saat itu lokasi pantai Base-G saat ini menjadi jaminan untuk penduduk asal Biak menempatinya. Ada juga jaminan dari pemerintah daerah setempat dan menjadi milik adat atau Pemda karena Hotel Numbay dan bar (tempat hiburan) tersebut adalah milik Pemda Papua saat itu. Batas hak ulayat pemukiman penduduk setempat dengan lokasi sekitarnya yang menjadi tempat wisata ditandai dengan adanya bekas pipa air minum. Lokasi Base-G merupakan milik adat setempat. Pemukiman orang Biak di Pantai Base- $G$ pernah diusulkan menjadi kampung tapi ditolak oleh pemda kota dan ditetapkan sebagai salah satu RT di Kelurahan Tanjung Ria karena alasan luas wilayah dan jumlah penduduk sambil mengikuti perkembangan penduduk di daerah tersebut.

Penduduk di Pantai Base-G saat diwawancarai mengemukakan bahwa sejak di daerah asal (Kampung Adadikam), pekerjaan yang dilakukan adalah sebagai petani dan nelayan. Ketika masih di kampung ekonomi menjadi baik karena bisa berkebun. Karena alasan keamanan (daerah kampung Adadikam yang menjadi salah satu Daerah Operasi Militer di Pulau Biak), sehingga sebagian besar masyarakat di kampung tersebut merasa tidak nyaman dan memilih pindah ke Kota Jayapura, khususnya di Pantai Base-G karena mempunyai hubungan kekeluargaan dengan Istri dari Bapak Frits Krey yang pertama kali menempati kawasan Pantai Base-G saat itu.

Pekerjaan sebagai nelayan biasanya tergantung musim ikan dan banyakknya ikan. Jika ikan yang didapat hanya satu jenis maka dijual secara eceran ke pedagang ikan dengan harga sekali jual sebesar Rp 1.000.000. Harga minimnya adalah Rp. 300.000. Penghasilan tambahan seperti 
menyewa pondok biasanya disesuaikan dengan hari libur. Ongkos sewa pondok sebesar Rp 150.000 hingga Rp 200.000 sekali pakai. Terdapat sekitar enam keluarga yang mempunyai pondok sewaan di pemukiman penduduk asal Biak di Base-G.

Cara melaut penduduk setempat adalah mancing ikan di daerah zona pecah gelombang dan tebarkan jaring di daerah terumbuh karang, atau melakukan mancing tunda. Untuk mancing biasanya menggunakan perahu dayung saat laut teduh. Jika menggunakan motor tempel minimal hanya 2 orang yang melaut dengan menggunakan motor tempel karena menjaga keseimbangan perahu dan pembagian tugas saat melaut yang tidak terlalu banyak membutuhkan banyak tenaga.

Bapak Frans Awom (salah satu migran asal Biak) yang saat ini menjabat sebagai Ketua RT 08, RW02, Kelurahan Tanjung Ria mengatakan dirinya saat ini selain bekerja sebagai buruh bangunan juga sebagai nelayan. Bapak Frans Awom mempunyai perahu jenis speed yang dibeli seharga Rp 13.000.000 dan motor tempel Rp 31.000.000. Perahu dayung dibuat sendiri dari sejenis pohon yang ditebang di daerah Ormu yang kualitasnya baik untuk dijadikan perahu dayung. Ikan yang didapat, biasanya dijual di Pasir Dua. Masyarakat setempat pendapatannya dari nelayan dan bangunan selain untuk konsumsi keluarga juga untuk ditabung. Ikan dijual di Pasir 2. Selama tinggal di daerah Base-G, masyarakat sekitar aktif di kegiatan-kegiatan di gereja dan kegiatan adat yang berkaitan dengan peminangan perempuan, urusan masalah adat yang menyangkut perempuan atau lakilaki yang bermasalah.

Untuk menjaga nilai-nilai adat penduduk setempat, ditetapkanlah struktur pemerintahan adat di lingkungan pemukiman orang Biak di Pantai Base-G yang selain untuk mengayomi hak-hak dasar penduduk setempat, juga mengayomi penduduk asal Biak lainnya di Jayapura. Beberapa penduduk asal Biak yang kemudian ditetapkan adalah Bapak Dorus Awom, sebagai tokoh adat, Bapak Frans
Awom dan Rumbiak sebagai penasehat. Bapak Dorus Awom kemudian diangkat sebagai Mananwir (Pemimpin Adat Orang Biak) di Jayapura untuk menjaga masyarakat asal Kampung Adadikam

Ketua Peradilan Adat untuk penyelesaian masalah-masalah adat diselesaikan oleh Ketua Peradilan Adat (Isak Ap), Yance Mambieuw, Darius Mamoribo. Sedangkan penasehat adalah Bapak Frans Awom. Keamanan daerah Base-G pada umumnya relatif aman..

Penduduk asal Biak di Base-G meskipun jauh dari sanak saudaranya di kampung halamannya, namun sering mengirim uang kepada sanak saudaranya ketika ada acara-acara keluarga seperti peminangan perempuan ataupun untuk kebutuhan keluarga lainnya seperti bangun rumah dan pendidikan anggota keluarga lainnya. Meskipun ada rencana untuk kembali ke daerah asal, namun belum ada keputusan karena anak-anak mereka lahir dan besar di Jayapura dan sedang berada di bangku sekolah sehingga keinginan untuk kembali ke kampung halaman belum bisa dipastikan.

Selama tinggal di Kota Jayapura dan menempati Kawasan Pantai Base-G, migran asal Biak di lokasi tersebut tidak terhindari dari beberapa penyakit, seperti malaria, batuk, ataupun pilek. Jika ada yang sakit, biasanya berobat ke rumah sakit terdekat selain mengonsumsi ramuan tradisional. Ramuan yang biasanya dikonsumsi adalah daun papaya atau daun bitanggur. Daun bintanggur digunakan untuk mengobati sakit mata. Hal ini merupakan tradisi masyarakat Biak.

Jarak ke tempat layanan kesehatan relatif jauh. Biasanya untuk pergi ke tempat layanan kesehatan digunakan kendaraan roda dua. Jika sakitnya memerlukan penanganan yang lebih serius maka harus ke rumah sakit. Selama di Pantai Base-G ada anak-anak yang meninggal karena sakit, kecelakaan dan dikuburkan di daerah Dok 9. Selama di Pantai Base-G masyarakat setempat selalu menjaga kekompakan dan kekeluargaan. 
Penyuluhan tentang lingkungan hidup dan bahaya kerusakan lingkungan hidup sudah dilakukan di daerah ini. Mengenai tempat sakral hanya ada di Pantai Base-G dan di daerah Kayu Batu di mana masyarakat dilarang untuk mandi di tempattempat tersebut. Jika melanggar dipercaya bisa tenggelam dan mati.

\subsection{Riwayat Migrasi, Faktor Pendorong dan Penghambat Migra Biak hingga Membentuk Pemukiman di Kawasan Pantai Base G}

Migrasi penduduk orang Biak yang saat ini menempati kawasan Pantai Base-G melakukan migrasi ke Jayapura karena persoalan keamanan dan ingin mencari pekerjaan. Migrasi orang Biak ke Jayapura mempunyai waktu bermigrasi yang berbedabeda antara satu dengan lainnya, baik dari tahun datang, transportasi yang digunakan, biaya perjalanan, dan banyaknya anggota keluarga yang digunakan dan alasan datang ke Jayapura.

Riwayat migrasi ke Jayapura berawal dari sejarah masa integrasi Papua ke dalam Negara Kesatuan Republik Indonesia. Pada tahun 1968, sudah ada penduduk orang Biak di Pantai Base-G Kota Jayapura yang sudah ada di Jayapura. Seperti yang dijelaskan di bagian awal tentang sejarah migrasi orang Biak di Pantai Base-G bahwa waktu kedatangan orang Biak di Pantai Base-G tidak bersamaan. Ada 3 orang yang datang pada tahun 1984 secara rombongan dan ada yang datang secara rombongan di waktu yang berbeda-beda. Hal ini berkaitan dengan hukum migrasi di mana salah satu faktor yang mendorong seseorang untuk bermigrasi ke suatu daerah adalah adanya faktor penarik dan faktor pendorong meskipun di antara keduanya ada yang disebut faktor rintangan.

Migran Biak yang datang ke Jayapura pada umumnya datang bersama keluarga, selain datang sendiri. Selain itu migran lainnya mengatakan lahir dan dibesarkan orang tuanya yang sudah lebih dahulu datang di Jayapura sejak 1960-an. Ketika datang ke Jayapura migran orang Biak membayar tarif transportasi paling rendah Rp 25.000 per orang dan pada 1990-an sekitar Rp 50.000.

Sejak datang di Jayapura, sebagian migran orang Biak langsung menempati Pantai Base-G hingga sekarang, sedangkan beberapa warga Biak lainnya yang belum menempati Pantai Base-G tinggal di beberapa keluarga Biak lainnya, yaitu di Sentani, Polimak, Jayapura Kota dan di kawasan Dok 9. Karena alasan ingin mempunyai tempat tinggal sendiri dan alasan bencana, penduduk tersebut sebagian besar memilih Pantai Base-G sebagai lokasi pemukiman baru hingga saat ini. Migran asal Biak datang ke Jayapura karena ajakan dari keluarga lainnya. Selain karena atas ajakan dari orang tuanya.

Pada umumnya migran orang Biak sebelum menempati kawasan Pantai Base-G hampir sebagian besar tersebar pada beberapa lokasi pemukiman di Kota Jayapura, Abepura, dan Sentani. Hanya beberapa orang saja yang langsung memilih Pantai Base-G sebagai lokasi tempat tinggal pertama kali ketika tiba di Jayapura. Selain di Dok 9 Kali, Pasir Dua, Nafri dan Polimak. Masuknya penduduk asal Biak lainnya untuk menempati kawasan Pantai Base-G karena alasan tempat tinggal yang dirasa perlu untuk memudahkan aktivitas sehari-harinya.

Berbagai alasan dikemukakan oleh migran Biak di Pantai Base-G Kota Jayapura mengenai alasan kepindahannya ke Jayapura. Beberapa alasan pokok yang dikemukakan adalah alasan politik atau gangguan keamanan, alasan mencari pekerjaan, dan alasan melanjutkan pendidikan. Beberapa alasan yang dikemukakan di atas, sangatlah beralasan karena dari riwayat pindahnya migran asal Biak ke Jayapura, berkaitan dengan situasi perkembangan politik yang terjadi di beberapa kota di Papua.

Cligget \& Crooks (Saptanto et. al., 2011), mengemukakan bahwa terdapat dua kelompok terkait dengan mobilitas tenaga kerja tersebut, yaitu 1) kelompok yang memandang migrasi merupakan pergerakan tenaga kerja sebagai akibat keterbatasan 
akses terhadap sumber daya dan tidak adanya peluang ekonomi pada daerah asal migran, dan 2) kelompok yang memandang migrasi merupakan perpindahan penduduk dari satu negara ke negara lain untuk mendapatkan pangan dan keamanan, serta untuk meningkatkan pendapatan keluarga.

Pulau Biak sebagai salah satu Kabupaten Kepulauan di Selat Saireri di Papua tidak terlepas dari gejolak politik pada saat itu. Operasi penumpasannya berada di bawah kekuasaan rezim Presiden Suharto. Gerakan politik oleh beberapa pentolan asal Biak yang pada saat itu terus diburu dengan tindakan kekerasan fisik maupun psikis dan dengan terbatasnya akses informasi, transformasi dan infrastruktur jalan seperti saat ini menyebabkan beberapa warga masyarakat di Kampung Adadikam memilih bermigrasi ke Jayapura. Hal ini karena mereka terus dihantui rasa takut dan trauma yang berkepanjangan dan berpengaruh terhadap pekerjaan sebagai petani dan peluang masa depan anak-anak. Kampung Adadikam adalah salah satu kampung di Distrik Biak Barat Kabupaten Biak Numfor yang ditetapkan sebagai Daerah Operasi Militer (DOM) oleh aparat keamanan Tentara Nasional Indonesia (TNI).

Faktor pendorong daerah asal migran Kabupaten Grobogan adalah: a) minimnya lapangan pekerjaan pada Kabupaten Grobogan, b) terbatasnya fasilitas pendidikan di Kabupaten Grobogan, c) bencana alam kekeringan, d) kemudahan mendapatkan pekerjaan di tempat tujuan, e) jarak terhadap lokasi yang dituju, f) adanya ajakan dari keluarga dan keperluan pribadi (Herdianti, 2019).

Alat transportasi yang lebih banyak digunakan responden ketika datang pertama kali di Jayapura adalah kapal laut (kapal perintis) berukuran kecil ataupun kapal berukuran besar (kapal putih). Hal ini sejalan dengan perkembangan transportasi laut sebelum memasuki tahun 1990-an, penduduk Papua pada umumnya lebih banyak menggunakan kapal perintis seperti Kapal Motor (KM) Pradawana, Teluk
Kabui, Dharma Nusantara, Nagura, dan beberapa kapal perintis lainnya.

Sekitar tahun 1980-an sudah ada Kapal Putih (Kapal berukuran besar, yakni KM. Umsini yang masuk Jayapura, namun tidak menyinggahi pelabuhan kapal pada beberapa kota di Papua. Kapal Umsini pada waktu itu hanya memasuki Pelabuhan Sorong dan Manokwari, lalu menuju Jayapura. Ketika memasuki tahun 1993 hingga sekarang (tahun 2020), mulai dioperasikan kapal berukuran besar seperti KM Ciremai, KM Nggapulu, KM Gunung Dempo, KM. Sinabung, KM. Tidar, KM. Labobar, yang mana kapal-kapal tersebut sebelumnya merupakan kapal penumpang yang melayani jalur pelayaran di Indonesia bagian Barat, Tengah dan daerah sekitar Selatan Papua.

Atas dasar jumlah dan distribusi penduduk pada beberapa kota di Papua dan disertai oleh adanya otonomi khusus di Papua maka berbagai kebutuhan layanan publik terus mengalir ke Papua, baik yang berhubungan dengan pendidikan, kesehatan, ekonomi dan infrastruktur. Pembangunan fisik dan non fisik di Jayapura sejak ditetapkan sebagai Ibu Kota Provinsi Papua, melahirkan berbagai kebijakan pembangunan di Jayapura dan pada umumnya, maka kebijakan pemerintah untuk menambah armada angkutan penumpang laut untuk berbagai suku bangsa di Indonesia, yang ingin ke Jayapura terus bertambah karena disesuaikan dengan arus migrasi di Kota Jayapura pada umumnya. Setiap migran, ketika sebelum menempati daerah baru sebelumnya telah mempunyai pola hidup yang tentu berbeda dengan kehidupan atau pola hidup di daerah yang baru ditempati.

Migran orang Biak mengaku sejak tinggal di daerah asalnya, bekerja sebagai nelayan dan petani. Di samping bekerja sebagai wiraswasta di daerah asalnya dan masih menumpang di rumah orang tua dan keluarga. Migran orang Biak mengatakan kehidupan di daerah asal, sangatlah susah, meskipun ketika migran orang Biak lainnya ketika datang ke Jayapura, menganggap 
kehidupan di Jayapura sama sekali tidak ada perubahan. Meskipun demikian sudah ada kesan bahwa ada kehidupan yang baik ketika migran asal Biak berada di Pantai Base-G Jayapura.

Ada kehidupan yang dianggap sangat susah di daerah tujuan menunjukkan kondisi ekonomi yang buruk pada saat itu, di mana konflik politik yang terus berkepanjangan di daerah asalnya dan tidak tersedia sarana transportasi laut dan darat yang memadai dalam menunjang ekonomi keluarganya seperti yang ada saat ini. Migran yang tidak mempunyai keahlian di daerah tujuan karena tidak mempunyai keahlian khusus dalam mencari pekerjaan di daerah tujuannya saat ini.

Todaro (Puspitasari, 2017), mengemukakan bahwa motivasi utama seseorang untuk mengambil keputusan bermigrasi adalah karena motif ekonomi. Menurutnya di dalam Expected Income model of rural-urban migration disebutkan bahwa motivasi tersebut sebagai pertimbangan ekonomi yang rasional, di mana mobilitas ke kota mempunyai dua harapan, yaitu harapan untuk memperoleh pekerjaan dan harapan untuk memperoleh pendapatan yang lebih tinggi daripada yang diperoleh di desa.

Dalam beradaptasi di daerah tujuan untuk menata kehidupan yang lebih baik, hampir dialami setiap kaum migran yang meninggalkan kampung halamannya dan memilih hidup di daerah lainnya. Hal ini dilakukan untuk beradaptasi dengan lingkungan baru di daerah yang baru ditempati, salah satunya dalam melakukan aktivitas sebagai nelayan seperti yang pernah dilakukan di daerah asalnya.

Migrasi komutasi atau sirkulasi antara desa pesisir dan daerah tujuan migrasi, merupakan upaya rumah tangga perikanan untuk melepaskan diri dari kemiskinan. Migrasi juga menyebabkan perubahan pola konsumsi rumah tangga dan membantu menyelesaikan masalah kerentanan pangan pada rumah tangga perikanan (Saptanto et. al., 2011).
Pada bagian yang lain disebutkan bahwa mobilitas penduduk dipicu oleh faktor pendorong (dari daerah pesisir) dan faktor penarik (dari daerah luar desa pesisir daerah tujuan migrasi). Faktor pendorong migrasi tersebut antara lain menipisnya potensi sumber daya ikan di perairan sekitar desa pesisir, terbatasnya akses masyarakat terhadap potensi ekonomi desa pesisir, terbatasnya lapangan kerja di desa pesisir, rendahnya harga hasil tangkapan nelayan. Faktor penariknya meliputi tersedianya lapangan kerja dengan upah yang pasti.

Penduduk yang meninggalkan daerah asalnya karena dirasakan kurang memberikan sumber kehidupan yang layak, menuju tempat lain anggap dapat memberikan harapan. Faktor-faktror yang mempengaruhi orang untuk melakukan migrasi sangat berperan dan rumit. Karena migrasi merupakan proses yang secara selektif mempengaruhi setiap individu dengan ciri-ciri ekonomi, sosial, pendidikan dan demografi tertentu. Kondisi sosial ekonomi di daerah yang tidak memungkinkan untuk memenuhi kebutuhan hidup, mendorong mobilisasi penduduk dengan tujuan mempunyai nilai dengan kefaedahan yang lebih tinggi di daerah tujuan. Salah satu cara baik dilakukan untuk mengatasi kesenjangan kesempatan ekonomi adalah dengan migrasi dari desa ke kota. Pertumbuhan penduduk besar diikuti persebaran tidak merata antara daerah dengan perekonomian yang cenderung terkonsentrasi di perkotaan mendorong masyarakat untuk bermigrasi (Ashari \& Mahmud, 2018).

Motivasi utama orang melakukan perpindahan dari daerah asalnya (perdesaan) ke perkotaan adalah karena motif ekonomi. Motif tersebut berkembang karena adanya ketimpangan ekonomi antardaerah. Kondisi yang paling dirasakan menjadi pertimbangan rasional, di mana individu melakukan mobilitas ke kota adalah adanya harapan untuk memperoleh pekerjaan dan memperoleh yang lebih tinggi daripada yang diperoleh di desa (Purnomo, 2009). 
Sandell dan Mincer (Marta, et. al., 2020), mengemukakan bahwa migrasi sebagai keputusan keluarga: Keluarga secara keseluruhan akan bermigrasu jika keungtungan bersih rumah tangga tersebut bernilai positif. Jika hanya satu pasangan yang menemukan pekerjaan (yang lebih baik) di daerah tujuan, maka keluarga hanya bermigrasi jika keuntungan dari satu anggota keluarga menginternasionalisasi kerugian anggota keluarga lainnya. Oleh karena itu, keputusan migrasi keluarga pada dasarnya merupakan kumpulan utilitas migrasi individu.

Todaro (Monanisa, 2017), mengemukakan bahwa fenomena migrasi di Indonesia karena banyaknya tenaga kerja dari desa bermigrasi mencari kerja di kota. Proses migrasi yang berlangsung dalam suatu negara (intermigration) dianggap sebagai proses alamiah yang akan menyalurkan surplus tenaga kerja di daerahdaerah ke sektor-sektor industri modern di kota-kota yang daya tampungnya lebih banyak, walaupun pada kenyataannya migrasi tenaga kerja dari desa ke kota telah melebihi daya tamping sektor jasa dan industry dan jasa di kota. Fenomena ini memberikan pola perubahan tersendiri di wilayah yang akan membentuk kota urban yang berkembang secara pesat.

Pola melaut yang biasanya digunakan migran Biak ketika mencari ikan di laut Base-G hingga pesisir Pasir Enam dan sekitarnya adalah menggunaan jaring ikan. Jenis jaring ikan yang biasanya digunakan adalah mata jaring berukuran 2 jari dan 3 jari. Kedua jenis ukuran mata jaring tersebut disesuaikan dengan jenis ikan yang biasanya hidup di daerah bebatuan dan mempunyai ukuran tertentu yang mudah terperangkap di ukuran mata jaring tersebut. Kawasan Pantai Base-G tergolong dalam jenis pesisir berpasir dan pesisir tektonik akibat gerakan sesar turun pada masa lampau. Sebaran bebatuan dan tumbuhan lamunnya memudahkan nelayan bisa melaut dengan menggunakan jaring ikan maupun memancing ikan pada saat air pasang.
Jenis perahu yang digunakan untuk melaut adalah perahu seman atau perahu dayung, dan perahu layar. Selain memancing saat air pasang atau air surut dan membuang jaring saat terjadi air pasang atau ketika menjelang air surut, terutama pada malam hari dan menjelang pagi hari di mana air laut sedang surut. Perubahan waktu pasang surutnya air menurut migran orang Biak yang diwawancarai, biasanya memudahkan untuk menangkap ikan dengan cara memancing ataupun menebarkan jaring.

Sebagai penduduk dari kampung yang tidak mempunyai pekerjaan tetap, beberapa pekerjaan yang sifatnya serabutan untuk dilakukan penduduk setempat adalah bekerja sebagai nelayan, buruh kasar, ataupun tukang bangunan. Sebagai buruh kasar ongkos kerja per harinya Rp 150.000. Sebagai tukang bangunan honornya $\mathrm{Rp}$ 250.000, sedangkan pekerjaan nelayan biasanya bersifat selingan ketika pekerjaan utama belum didapat dan kondisi laut sedang baik. Ongkos kerja biasanya dibayarkan dua minggu sekali atau sebulan sekali.

Jika pekerjaan sebagai buruh kasar atau tukang bangunan dilakukan di luar Jayapura, seperti di Arso, Genyem atau Sarmi atau kabupaten lainnya, tarif kerja perharinya sedikit bertambah dibanding ketika bekerja di sekitaran kota Jayapura.

Pekerjaan sebagai nelayan biasanya tergantung musim ikan dan banyakknya ikan. Jika ikan yang didapat hanya satu jenis maka dijual secara eceran ke pedagang ikan dengan harga sekali jual sebesar $\mathrm{Rp}$ 1.000.000. Harga minimnya adalah $\mathrm{Rp}$ 300.000. Penghasilan tambahan seperti menyewa pondok biasanya disesuaikan dengan hari libur. Ongkos sewa pondok sebesar Rp 150.000 hingga Rp 200.000 sekali pakai. Terdapat sekitar enam keluarga yang mempunyai pondok sewaan di pemukiman penduduk asal Biak di Base-G.

Untuk meningkatkan ekonomi keluarga sebagian besar migran orang Biak mengatakan mempunyai tabungan di bank dan sebagiannya tidak punya tabungan di bank. Kepemilikan tabungan berkaitan dengan tingkat pendapatan responden dari 
hasil melaut maupun dari hasil kerja sebagai buruh bangunan.

Pendapatan diartikan sebagai hasil yang diperoleh setelah bekerja, pendapatan yang diperoleh tanpa memberikan suatu kegiatan apapun, yang diterima oleh para migran di suatu negara. Seseorang pada mulanya melakukan migrasi dengan harapan untuk mendapatkan pendapatan yang lebih tinggi, karena pendapatan yang ada di daerah asal dirasakan kurang mencukupi untuk memenuhi kebutuhannya, sehingga menyebabkan seseorang individu mengambil keputusan untuk bekerja di luar negeri. Penjelasan tersebut bermakna jika memiliki pengaruh positif terhadap migrasi, karena bekerja di luar negeri para migran dapat memperoleh pendapatan yang lebih tinggi dan cukup untuk biaya kebutuhan individu tanggungannya. Selisih pendapatan tersebut mendorong migran untuk lebih lama bekerja di luar negeri (Purnomo, 2009).

Berbagai kota besar di Pulau Jawa, biasanya migran yang bekerja di kota-kota besar, selalu dijadikan tulang punggung keluarga oleh keluarganya di daerah asal. Hal ini menggambarkan bahwa responden yang berada di daerah rantauan jelas mempunyai pekerjaan yang dapat menjanjikan untuk diberikan kepada keluarga di daerah asalnya.

Meskipun migran orang Biak mengaku sudah tinggal di Pantai Base-G selama kurang lebih 30-an tahun namun sebagian besar migran di daerah tersebut mengatakan akan kembali ke daerah asalnya. Sebagian yang lain mengatakan tidak akan kembali ke daerah asalnya. Migran yang mengatakan akan kembali ke daerah asalnya berkaitan dengan riwayat pekerjaannya di daerah tujuan saat ini yang tidak memungkinkan untuk ditinggali selamanya, sedangkan migran yang mengatakan tidak akan kembali ke daerah asalnya karena persoalan pekerjaan dan pendidikan anak-anaknya sehingga lebih memilih menetap di Kota Jayapura.

Selama tinggal di Kota Jayapura dan menempati Kawasan Pantai Base-G, migran asal Biak di lokasi tersebut tidak terhindari dari beberapa penyakit, seperti malaria, batuk, ataupun pilek. Jika ada yang sakit, biasanya berobat ke rumah sakit terdekat selain mengonsumsi ramuan tradisional. Ramuan yang biasanya dikonsumsi adalah daun papaya atau daun bitanggur. Daun bintanggur digunakan untuk mengobati sakit mata. Hal ini merupakan tradisi masyarakat Biak.

Jarak ke tempat layanan kesehatan relatif jauh. Biasanya untuk pergi ke tempat layanan kesehatan digunakan kendaraan roda dua. Jika sakitnya memerlukan penanganan yang lebih serius maka harus ke rumah sakit.

Selama di Pantai Base-G ada anak-anak yang meninggal karena sakit, kecelakaan dan dikuburkan di daerah Dok 9. Lokasi pemakaman harga liangnya mencapati $\mathrm{Rp}$ 2.000.00 hingga Rp 3.000.000 satu liangnya. Selama di Pantai Base-G masyarakat setempat selalu menjaga kekompakan dan kekeluargaan.

Penyuluhan tentang lingkungan hidup dan bahaya kerusakan lingkungan hidup sudah dilakukan di daerah ini. Mengenai tempat sakral hanya ada di Pantai Base-G dan di daerah Kayu Batu di mana masyarakat dilarang untuk mandi di tempattempat tersebut. Jika melanggar dipercaya bisa tenggelam dan mati.

\section{Kesimpulan}

Adapun kesimpulan pada penelitian ini orang Biak bermigrasi ke Kota Jayapura karena alasan pekerjaan dan keamanan. Karena alasan tempat tinggal, migran asal Biak tidak seluruhnya menempati Kawasan pantai Base-G secara bersama-sama. Migran Biak di Pantai Base-G bekerja sebagai buruh bangunan dan nelayan. Lokasi pemukiman di daerah ini diperkirakan akan terus bertambah dan melebar dengan banyaknya keluarga migran dengan tingkat fertilitas yang terus berlangsung setiap tahun.

Berdasarkan hasil penelitian tersebut diperlukan program pemerintah yang berkaitan dengan pemberdayaan masyarakat untuk meningkatkan kualitas hidup penduduk setempat seperti pemberian 
bantuan modal usaha dalam menunjang pekerjaan sebagai buruh dan nelayan perlu diperhatikan. Selain itu, pengakuan dari pemerintah adat dan pemerintah Kota Jayapura dalam menetapkan status pemukiman penduduk setempat sebagai salah satu kampung perlu dipertimbangkan. Serta, perlu adanya penyuluhan bagi warga setempat mengenai pelestarian alam bahari pantai Base-G.

\section{Daftar Pustaka}

Ahimsa-Putra, H. S. (2009). Strukturalisme Levi-Strauss: Mitos dan Karya Sastra. Yogyakarta: Keppel Press.

Ashari, M. I., \& Mahmud, A. K. (2018). Apakah yang mempengaruhi Fenomena Migrasi Masuk ke Wilayah Perkotaan? Ecces, Vol, 5 No.1, EcceS (Economics, Social, and Development Studies), 5(1), 61-79. doi: https://doi.org/10.24252/ecc.v5i1.523 7

Frank, S. A., Rumere, J., \& Lewakabessy, B. (2015). Persebaran Orang Biak di Kepulauan Komamba, Sarmi-Papua (1th ed.). Yogyakarta: Kepel Press

Herdianti, S. (2019). Analisis Migrasi Risen berdasarkan Hasil Survei Penduduk Antar Sensus (SUPAS) Tahun 2015 di Kabupaten Grobogan, Jawa Tengah. Prosiding Seminar Nasional Geografi UMS X 2019.

Husnah, A., Sentosa, S. U., \& Anis, A. (2019). Faktor-Faktor yang Mempengaruhi Migrasi Seumur Hidup di Indonesia. Jurnal Kajian Ekonomi dan Pembangunan, 1(2), 331-340. doi: http://dx.doi.org/10.24036/jkep.v1i2. 6175

Huwae, M. A., Hanif, F. M., \& Rumbekwan, K. (2018). Redefining Tourism Governance in Raja Ampat: Sustainable Development Plus, Governance Index and Android Based App Open Access. Jurnal
Perencanaan Pembangunan: The Indonesian Journal of Development Planning, 2(3), 309-319. Retrieved from

http://journal.bappenas.go.id/index.p hp/jpp/article/view/40

Lausiry, M. N., \& Tumuka, L. (2019). Analisis Kondisi Sosial-Ekonomi Masyarakat Migran Sebelum dan Sesudah Berada di Kota Timika. JURNAL KRITIS (Kebijakan, Riset, dan Inovasi), 3(1), 1-23. Retrieved from

http://ejournal.stiejb.ac.id/index.php/j urnal-kritis/article/view/43/33

Marta, J., Fauzi, A., Juanda, B., \& Rustiadi, E. (2020). Migrasi Desa-Kota di Indonesia:"Risk Coping Strategy vs Investment". Jurnal Ekonomi dan Pembangunan Indonesia, 20(2), 160$173 . \quad$ doi: https://doi.org/10.21002/jepi.v20i2.1 337

Monanisa, M. (2017), Fenomena Migrasi Tenaga Kerja dan Perannya Bagi Pembangunan Daerah di Oku Selatan. JURNAL SWARNABHUMI: Jurnal Geografi dan Pembelajaran Geografi, 2(1), 59-64. Doi: http://dx.doi.org/10.31851/swarnabhu mi.v2i1.1138

Oktafiani, I., \& Jogaswara, H. (2019). Migrasi Orang Biak dan Identitas Orang Asli Papua di Sausapor, Papua Barat. Antropologi Indonesia, 40(1), 1-18.

Doi: https://doi/org/10.7454/ai.v40i1.1127 8

Purnomo, D. (2009). Fenomena Migrasi Tenaga Kerja dan Perannya bagi Pembangunan Daerah Asal Studi Empiris di Kabupaten Wonogiri. Jurnal Ekonomi Pembangunan, Vol. 10. No. 1, Edisi Juni 2009.10(1), 84102.

Doi: https://doi.org/10.23917/jep.v10i1.81 0 
Puspitasari, W. I. (2017). Faktor-Faktor yang Mempengaruhi Migrasi Tenaga Kerja ke Luar Negeri Berdasarkan Provinsi di Indonesia. Jurnal Ilmu Ekonomi Terapan, 2(1), 49-64. doi: http://dx.doi.org/10.20473/jiet.v2i1.5 505 (1): 49-64

Saberia, S., Parera, A. M. F., \& Yamin, A. (2016). Orang Tobelo di Kampung Lemalas: Sejarah dan Peran Orang tobelo di Distrik Misool Timur Kabupaten Raja Ampat (1th ed.). Jayapura: Kementerian Pendidikan dan Kebudayaan, Direktorat Jenderal Kebudayaan Balai Pelestarian Nilai Budaya Papua

Saptanto, S., Lindawati, L., \& Zulham. (2011). Analisis Pola Migrasi dan Konsumsi Rumah Tangga di Deaerah Asal Migrasi Tterkait Kkemiskinan dan Kerentanan Pangan (Kasus Studi Studi Kasus Indramayu). Jurnal Organisasi dan Manajemen, 7(1) 2137. Retrieved from http://jurnal.ut.ac.id/index.php/jom/ar ticle/view/81

Sasmi, C., \& Bachtiar, N. (2014). Analisis Migrasi Internal di Sumatera Barat: Suatu Kajian Faktor-faktor yang mempengaruhi migrasi masuk ke Kota Padang. Retrieved from http://repo.unand.ac.id/5114/

Sudubia, K., Rimbawan, D., \& Adnyana. I. B. (2012). Pola Migrasi dan Karakteristik Migran Berdasarkan Hasil Sensus Penduduk 2010 di Pulau Bali. Piramida, 8(2), 59-75. Retrieved from https://ojs.unud.ac.id/index.php/pira mida/article/download/6996/5245

Trendyarti, A. A. T., \& Yasa, I. N. M. (2014). Analisis Faktor-Faktor yang mempengaruhi Migrasi Masuk ke Kota Denpasar. E-Jurnal Ekonomi Pembangunan, 3(10) 431-484. Retrieved from https://ojs.unud.ac.id/index.php/eep/a rticle/download/9417/7580

Usmany, D. P. (2014). Pelayaran Orang Biak Numfor sebelum Abad 19 Suatu Tinjauan Sejarah Maritim. Jnana Budaya, 19(2), 199-216. Retrieved from

https://jurnalbpnbbali.kemdikbud.go.i $\mathrm{d} /$ jurnal/index.php/Jnana/article/view $/ 16 / 16$ 